\title{
Inhibition of ethylene response by 1-methylcyclopropene in potted ornamental pepper
}

\author{
Inibição das respostas ao etileno por 1-methylcyclopropeno em pimenta ornamental de vaso
}

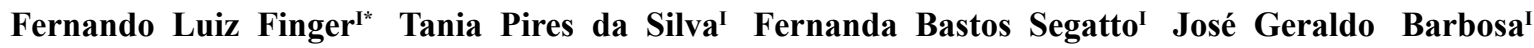

\section{ABSTRACT}

In the face of great potential of 1-MCP in blocking ethylene action, this study aimed to evaluate the efficacy of 1-MCP on ethylene action and extend the post-production of ornamental peppers Capsicum annum potted plants. Ornamental pepper cultivar Calypso shows complete abscission of leaves when exposed to $10 \mu \mathrm{L} \mathrm{L} L^{-1}$ ethylene. By exposing plants to ethylene, significant drops on $a, b$ and total chlorophyll were found at the end of the treatment. Nevertheless, no changes on leaf total carotenoid were observed after the treatment with ethylene. When the plants were treated with 1-methylcyclopropene (1-MCP), followed or not by treatment with ethylene, contents of $a, b$, total chlorophyll and carotenoid remained unchanged. Control plants showed no changes in chlorophylls or carotenoid contents after 48 hours from moving the pots from greenhouse to indoor conditions illuminated with white fluorescent light. The 1-MCP was able to prolong the post production shelf life, by inhibiting the abscission of leaves. Plants treated with 1-MCP, followed by ethylene had $38 \%$ accumulated leaf abscission, after 18 days of post production life, similar to control plants. After the same period, plants treated only with 1-MCP had 22\% leaf abscission. The 1-MCP partially blocked ethylene and induced leaf abscission. Regardless which treatment was applied during post production life, there was a continuous decrease on leaf chlorophyll content beyond $18^{\text {th }}$ day. Thus, 1-MCP was effective in preventing leaf abscission even in the presence of ethylene, avoiding deleterious effects of ethylene by blocking its receptor sites.

Key words: Capsicum annuum, chlorophyll, leaf abscission, post production.

\section{RESUMO}

Em face do grande potencial de utilização do 1-MCP no bloqueio da ação do etileno, este trabalho teve como objetivo avaliar a eficiência do 1-MCP em bloquear a ação do etileno e estender a vida pós-produção de plantas de pimenta ornamental da espécie Capsicum annuum. A pimenta ornamental, cultivar Calypso, apresenta abscisão completa das folhas quando exposta a $10 \mu \mathrm{L} \mathrm{L}^{-1}$ de etileno. Nas plantas expostas ao etileno, houve reduções significativas dos teores de clorofila $a, b$ e total ao final do tratamento. Nenhuma alteração no conteúdo de carotenoides total das folhas foi observada após o tratamento com etileno. Quando as plantas foram tratadas com 1-metilciclopropeno (1$\mathrm{MCP}$ ), seguido ou não pelo tratamento com etileno, os teores de clorofila $a, b$, total e carotenoides permaneceram inalterados. As plantas controle não apresentaram alterações nas clorofilas ou carotenoides, após 48 horas da remoção dos vasos da estufa para recinto fechado iluminado com luz branca fluorescente. $O$ 1-MCP foi capaz de prolongar a vida de prateleira semelhante às plantas controle. No mesmo periodo, plantas tratadas somente com 1-MCP tiveram $22 \%$ de abscisão foliar. $O$ tratamento com 1-MCP bloqueou parcialmente a queda das folhas induzida por etileno. Independentemente do tratamento aplicado, houve diminuição contínua do teor de clorofila das folhas após o $18^{\circ}$ dia. A fumigação com 1-MCP foi eficaz na pós-produção, inibindo a abscisão das folhas. Plantas tratadas com 1-MCP, seguido por etileno, tiveram 38\% de abscisão foliar acumulada, após 18 dias de vida em pós-produção, prevenção da queda de folhas, mesmo na presença de etileno, evitando os efeitos deletérios de etileno, através do bloqueio dos sitios receptores de etileno.

Palavras-chave: Capsicum annuum, clorofila, abscisão foliar, pós-produção.

\section{INTRODUCTION}

Search for new commercial ornamental products has increased steadily over the past 50 years (SCHOELLHORN, 2009). In particular, the demand for potted ornamental peppers has experienced large increase in the past decade, in both Brazilian and international floricultural markets. Nevertheless, there are only a few options of cultivars available for ornamental purposes. In addition to that, studies

${ }^{\text {I} U n i v e r s i d a d e ~ F e d e r a l ~ d e ~ V i c ̧ o s a ~(U F V), ~ 36570-900, ~ V i c ̧ o s a, ~ M G, ~ B r a s i l . ~ E-m a i l: ~ f f i n g e r @ u f v . b r . ~ * C o r r e p o n d i n g ~ a u t h o r . ~}$ 
regarding the behavior of Capsicum species grown in pots and the influence of environmental factors on longevity are still scarce.

Cultivar 'Calypso' is very popular among Capsicum ornamental peppers being cultivated in Brazil and elsewhere. Despite its colorful fruits and compact canopy, Calypso has short post production longevity, due to high rate of leaf abscission when exposed to relative low ethylene (SEGATTO et al., 2013). In this research, relatively low concentrations as $10 \mu \mathrm{L} \mathrm{L}^{-1}$ of ethylene was able to cause complete drop of leaves in less than 48 hours.

The 1-Methylcyclopropene (1-MCP) is the most effective commercial substance enables to block ethylene action in climacteric and non climacteric fruits, green leafy vegetables and many species of ornamental plants. In cut orchid flowers of Epidendrum ibaguense, treatment with 1-MCP increased longevity by reducing flower abscission and wilting (FINGER et al., 2008). Fumigation with 1-MCP has been effective in blocking the negative effects of ethylene different flowers, including some varieties of roses, geranium, phalaenopsis, diantus, gentian and inflorescences of Oncidium varicosum (SEGLIE et al., 2010; SHIMIZU-YUMOTO \& ICHIMURA, 2012; MATTIUZ et al., 2012). In this research, 1-MCP was applied to prevent abscission and yellowing of leaves in potted ornamental pepper cultivar 'Calypso' applied at post production shelf stage.

\section{MATERIAL AND METHODS}

Seeds from cultivar 'Calypso' (Capsicum annuum L.) were sown in trays with single cells and transplanted to $760 \mathrm{ml}$ pots when the plantlets had 4 to 5 true leaves. Pots were filled with commercial substrate Plantmax ${ }^{\circledR}$ and the plants grown in a greenhouse for four months until they were ready for commercial sale. Plants were fertilized weekly with a water diluted (1:10) solution of $150 \mathrm{~g} \mathrm{~L}^{-1}$ of commercial Ouro Verde (15-15-20 NPK + Ca, S, Mg, Zn, B, Fe, and $\mathrm{Mn}$ ). Commercial stage for sale was defined when $30 \%$ of fruits were ripe, afterwards, pots were transferred to a indoor room at $25^{\circ} \mathrm{C}$, illuminated for 12 hours period with white fluorescent light during the experimental period. Pots were then placed in a 60L container for 1-MCP and ethylene treatment and controls. Plants of all treatments were kept at $25 \pm 1{ }^{\circ} \mathrm{C}$ under white fluorescent light with intensity of $8-10 \mu \mathrm{mol} \mathrm{s} \mathrm{m}^{-1} \mathrm{~m}^{-2}, 60-65 \%$ relative humidity and watered when needed.

Plants were treated with $1 \mu \mathrm{L} \mathrm{L}^{-1} 1-\mathrm{MCP}$ for $6 \mathrm{~h} ; 1 \mu \mathrm{L} \mathrm{L}^{-1} 1-\mathrm{MCP}$ for $6 \mathrm{~h}+$ followed by $10 \mu \mathrm{L}$
$\mathrm{L}^{-1}$ ethylene for $48 \mathrm{~h}$ and $10 \mu \mathrm{L} \mathrm{L}^{-1}$ ethylene for $48 \mathrm{~h}$ (SEGATTO et al., 2013). Two controls were set up, in control 1, plants kept inside 60L containers for 48 hours, and for control 2, plants kept on laboratory bench, totaling five treatments.

Following the treatments, leaf and fruit abscissions were determined daily by counting the total dropped amount during all the period of shelf life, expressed in percentage. Longevity and yellowing of the leaves were determined at every three days from first day after treatment, up to 18 days. End of longevity was determined when the pepper plants did not have commercial value $(50 \%$ of leaf and fruit abscission and/or 50\% yellowing of leaves). Leaf yellowing was determined by SPAD 502 (Minolta, Japan) over ten measurements on the attached leaves.

Controls, 1-MCP and/or ethylene treated plants were evaluated before and after 1-MCP and/ or ethylene treatments for leaf chlorophylls and total carotenoids contents. Pigments were extracted with $80 \%$ acetone from fully expanded leaves and absorbances recorded in spectrophotometer according to method described by LICHTENTHALER (1987).

Experiment was arranged in a complete randomized block design with five replicates of one pot each, totaling 25 pots. The data were statistically analyzed using analysis of variance (ANOVA) and significance among treatments was performed by Student's t-test at $\mathrm{P} \leq 0.05$. Regression at $\mathrm{P} \leq 0.05$ analysis was used to estimate the rate of chlorophyll degradation during post production shelf life.

\section{RESULTS AND DICUSSION}

In both control plants and those treated with 1-MCP showed no reduction on chlorophyll $a, b$ and total contents after 48 hours of post production shelf life (Table 1). But, when they were exposed to $10 \mu \mathrm{L}$ $\mathrm{L}^{-1}$ ethylene for 48 hours, significant drop on content of leaf chlorophylls took place. The presence of ethylene for 48 hours induced breakdown of chlorophyll $b$, but not on chlorophyll $a$ (Table 1). Thus, by end of ethylene treatment, leaves had lost $27.6 \%$ of total chlorophyll. Ethylene acts by converting chlorophyll $a$ and $b$ in chlorophyllide and phytol, resulting in loss of green color usually at concentration varying from 1 to $10 \mu \mathrm{L} \mathrm{L}^{-1}$ (FERRANTE \& FRANCINI, 2004). The same authors mention that ethylene increases activity of chlorophyllase and oxidases responsible for chlorophyll degradation by regulating up their gene expression, in the presence or absence of light. In this research, when 1-MCP is applied before exposing the 
Table 1 - Changes in the leaf pigments of ornamental pepper (Capsicum annuum) cultivar 'Calypso' before and after being submitted to 1MCP and ethylene. Plants were kept under white fluorescent light at $8-10 \mu \mathrm{mol} \mathrm{s}^{-1} \mathrm{~m}^{-2}$.

\begin{tabular}{|c|c|c|c|c|c|}
\hline Treatments & $1-\mathrm{MCP}^{\mathrm{a}}$ & Ethylene $^{\mathrm{b}}$ & 1-MCP+Ethylene ${ }^{\mathrm{c}}$ & Control $1^{\mathrm{d}}$ & Control $2^{\mathrm{e}}$ \\
\hline Before & 4.02 & 3.89 & 4.44 & 4.47 & 4.28 \\
\hline \multirow[t]{2}{*}{ After } & $4.12^{\mathrm{ns}}$ & $3.00^{\mathrm{ns}}$ & $4.23^{\mathrm{ns}}$ & $3.97^{\mathrm{ns}}$ & $4.36^{\mathrm{ns}}$ \\
\hline & & & Chlorophyll b (mg & - & \\
\hline Before & 1.56 & 1.90 & 1.84 & 1.55 & 1.43 \\
\hline \multirow[t]{2}{*}{ After } & $1.20^{\mathrm{ns}}$ & $1.26 *$ & $1.82^{\mathrm{ns}}$ & $1.63^{\mathrm{ns}}$ & $1.49^{\mathrm{ns}}$ \\
\hline & & (-) & otal chlorophyll (n & - & \\
\hline Before & 5.58 & 5.80 & 6.28 & 6.02 & 5.49 \\
\hline \multirow[t]{2}{*}{ After } & $5.32^{\mathrm{ns}}$ & $4.20 *$ & $6.08^{\mathrm{ns}}$ & $5.60^{\mathrm{ns}}$ & $5.79^{\mathrm{ns}}$ \\
\hline & & 西 & otal carotenoid (m & & \\
\hline Before & 0.83 & 0.98 & 0.68 & 0.75 & 0.97 \\
\hline After & $0.81^{\mathrm{ns}}$ & $0.86^{\text {ns }}$ & $0.81^{\mathrm{ns}}$ & $0.70^{\text {ns }}$ & $0.88^{\text {ns }}$ \\
\hline
\end{tabular}

${ }^{\mathrm{ns}}$ non significant and ${ }^{*}$ significant at probability level of $P=0.05$ by Student's $t$ test.

${ }^{a}$ Plants treated with $1 \mu \mathrm{L} \mathrm{L}^{-1} 1$-MCP for 6 hours.

${ }^{\mathrm{b}}$ Plants treated with $10 \mu \mathrm{L} \mathrm{L}^{-1}$ ethylene for 48 hours.

${ }^{\mathrm{c}}$ Plants $1 \mu \mathrm{L} \mathrm{L}^{-1} 1$-MCP for 6 hours, followed by $10 \mu \mathrm{L} \mathrm{L}^{-1}$ ethylene for 48 hours.

${ }^{\mathrm{d}}$ Control 1, plants kept for 48 hours in the closed containers.

${ }^{\mathrm{e}}$ Control 2, plants kept on the bench.

plants to ethylene, degradation of chlorophyll induced by ethylene is bloked (Table 1). Thus, pepper plants treated with 1-MCP before being exposed to ethylene, blocked the receptor sites preventing ethylene action, and subsequent yellowing and leaf abscission. The 1-MCP treatment also prevented onset of ripening of guavas, delaying the loss of fruit firmness and kept green skin color (CERQUEIRA et al., 2009). In broccoli, 1-MCP was able to reduce chlorophyllase activity, yellowing, and consequently increase on floret postharvest shelf life (WATKINS, 2006)

Although a role for endogenous ethylene in mediating the phenotypic changes associated with fruit ripening in pepper has not been yet determined, ethylene treatments can lead to enhanced carotenoid accumulation (FOX et al., 2005). But, for cultivar 'Calypso', regardless the treatment applied, ethylene did influence the carotenoid contents in leaves, which were similar before or after being treated with ethylene or 1-MCP (Table 1).

Exposure of cultivar 'Calypso' to $10 \mu \mathrm{L} \mathrm{L}^{-1}$ ethylene for 48 hours induced abscission of $100 \%$ of leaves during treatment, but did not induce any fruit abscission (data not shown). Ethylene effectiveness on pepper fruit abscission depends on length of exposure, concentration, temperature, stage of development and sensitivity of species or variety (WATKINS \& NOCK, 2012; SEREK et al., 2006). This research confirms the high sensitivity of cultivar 'Calypso' leaves to ethylene previously identified by SEGATTO et al. (2013). As in this research, they determined that ethylene was responsible for total loss of commercial value cultivar 'Calypso' when exposed to a threshold level of ethylene, mainly by triggering the abscission of leaves. The 1-MCP significantly extended longevity of phalaenopsis flowers, regardless of presence or absence of ethylene in atmosphere after being treated with 1-MCP (CHANG et al., 2013) and also in roses from cultivar Sparkle (NERGI \& AHMADI, 2014). According to (CHITARRA \& CHITARRA, 2005), effectiveness of 1-MCP in blocking ethylene action varies among the plant species, stage of development, plant maturity, concentration, length of treatment and temperature during treatment.

Sensitivity of ornamental plants to ethylene is roughly established at family level, but marked differences exist among species and cultivars (SEREK et al., 2006). Such behavior was also determined in four ornamental peppers cultivars belonging to species $\boldsymbol{C}$. annuum, where the cultivar 'Calypso' showed the highest level of response to ethylene (SEGATTO et al., 2013). In order to improve post production life of this cultivar, it is necessary to block the ethylene receptors before exposing the plant to ethylene during shipping, storage and retail sales or when plants are submitted to any stress that induces ethylene production.

There are several problems encountered at post-production stage that affect the quality and vase life of ornamental plants in general and, e ethylene exposure are one of the most important. 
Build up of ethylene in the atmosphere occurs mainly during transport and retail sales, which effects are increased by stresses, such as low light intensity and high temperatures (TAIZ \& ZEIGER 2004; SA et al., 2008). In general, rate of ethylene production increases with plant development, physical injuries, incidence of disease, temperature up to $35^{\circ} \mathrm{C}$ and water stress. In several ornamental species, ethylene exerts plays an important role by enhancing senescence, which results in deterioration of tissues and consequent reduction of postharvest life. Also, in some organs like in flowers of Dendrobium, ethylene can trigger autocatalysis, resulting in its own massive production (LERSLERWONG \& KETSA, 2008).

The 1-MCP treated plants had the lowest rate of leaf abscission during post production shelf life, and after 18 days, only $22 \%$ of leaves had dropped, while control plants showed up to $50 \%$ of abscission (Figure 1). In conclusion, 1-MCP was able to retard the abscission of leaves even when higher levels of ethylene were present in the atmosphere. Nevertheless, when a damaging level of ethylene was present after being treated with 1-MCP, some abscission of leaves occurred (Figure 1). This fact is clearly shown at $18^{\text {th }}$ day of post-production shelf life, where the 1-MCP + Ethylene treated plants had an intermediate behavior regarding the rate of leaf abscission and accumulated defoliation, standing between controls and 1-MCP treated plants. Prolongation freshness and quality of flowers and fruits by treating with 1-MCP is commercially used and recommended, which brings benefits to farmers, wholesalers, retail stores and consumers (PIRRUNG et al., 2008).

Similarly to peppers, post-production quality was also maintained when Regal Pelargonium genotypes were pretreated with 1-MCP before being exposed to exogenous ethylene (KIM et al., 2007). However, 1-MCP did not prevent petal abscission of new open flowers. Thus, similar to the results obtained in this experiment, pretreatment with 1-MCP complements the resistance to ethylene, but does not reduce the sensitivity to its action once the treatment is over. It has been suggested that only by incorporating genes of resistance in new cultivars will make it possible to improve the longevity of ethylene-sensitive ornamental plants.

Except for ethylene treated pots, which had complete loss of the leaves, a persistent decline of chlorophyll took place during post-production period (Figure 2). Nevertheless, the rate of decline

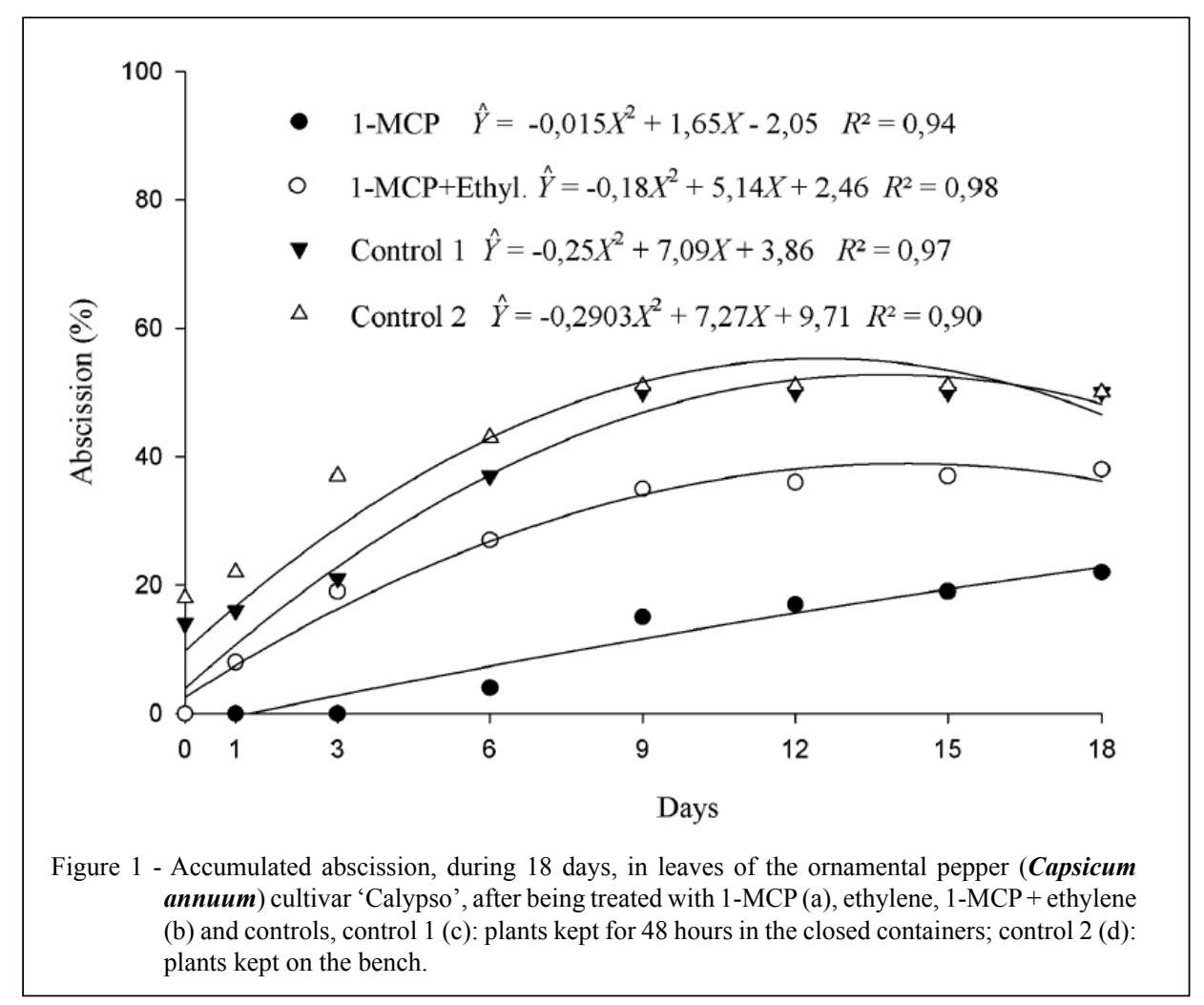

Ciência Rural, v.45, n.6, jun, 2015. 


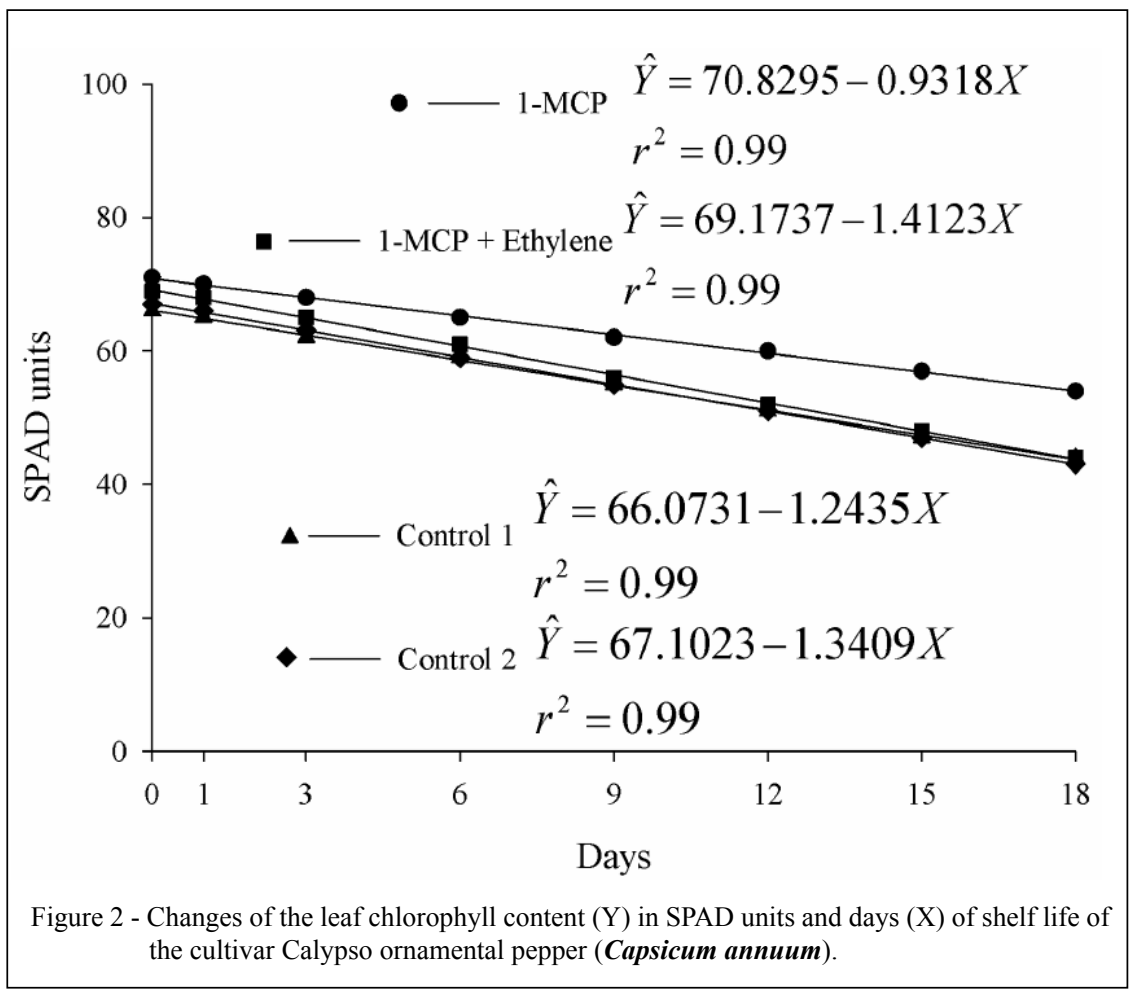

varied according to treatments. The highest rate of decrease 1.407 SPAD units per day was determined in plants that were pretreated with 1-MCP followed by ethylene (Figure 2). This result shows that despite the fact of pretreatment with 1-MCP, ethylene was able to partially overcome the blocking action of 1-MCP.

MA et al. (2009) working with broccoli found that 1-MCP delayed yellowing of florets, but the generation of new receptors will recover the sensitivity to ethylene, and as consequence, chlorophyll degradation will return. This phenomenon occurred in a much less intensity in plants treated with 1-MCP, since their leaves lost 0.903 SPAD units per day (Figure 2). In conclusion, 1-MCP treatment was effective in partially preventing the sudden fall of leaves in presence of exogenous ethylene.

\section{ACKNOWLEDGEMENTS}

The research was supported in part by a grant from Fundação de Amparo à Pesquisa do Estado de Minas Gerais (FAPEMIG). Scholarships were provided by Coordenação de Aperfeiçoamento de Pessoal de Nível Superior (CNPq).

\section{REFERENCES}

CERQUEIRA, T.S. et al. Controle do amadurecimento de goiabas 'Kumagai' tratadas com 1-metilciclopropeno. Revista Brasileira de Fruticultura, v.31, p.687-692, 2009. Available from: $\quad<$ http://www.scielo.br/scielo.php?script=sci arttext\&pid $=$ S0100-29452009000300010>. Accessed: Oct. 8, 2014 .

CHANG, Y.C.A. et al. Concentration of 1-methylcyclopropene and the duration of its application affect anti-ethylene protection in Phalaenopsis. Scientia Horticulturae, v.153, p.117-123, 2013. Available from: $<$ http://www.sciencedirect.com/science/article/pii/ S0304423813000666>. Accessed: Sept. 12, 2014. doi: 10.1016/j. scienta.2013.02.003

CHITARRA, M.L.F.; CHITARRA, A.B. Pós-colheita de frutos e hortaliças - fisiologia e manuseio. Lavras: ESAL/FAEP, 2005. 785p.

FINGER, F.L. et al. Longevity of Epidendrum ibaguense flowers as affected by pre-loading treatments and vase solution. Journal of Horticultural Science \& Biotechnology, v.83, p.144-147, 2008. Available from: $<$ http://www.scielo.br/scielo.php?script=sci nlinks\&ref=000074\&pid=S1516-8913201200020000400003\&lng $=$ en $>$. Accessed: Sept. 13, 2014.

FOX, A.J. et al. Ripening-induced chemical and antioxidant changes in bell peppers as affected by harvest maturity and postharvest ethylene exposure. Hortscience, v.40, p.732-736, 2005.

FERRANTE, A.; FRANCINI, A. Ethylene and leaf senescence. In: KHAN, A.N. Ethylene action in plants. Netherlands: Springer, 2006. p.51-67.

KIM, H.-J. et al. Ethylene resistance of Regal Pelargonium is complemented but not replaced by 1-MCP. Postharvest Biology and Technology, v.45, p.66-72, 2007. Available from: <http:// 
www.sciencedirect.com/science/article/pii/S0925521407000257>. Accessed: May 2, 2013. doi: 10.1016/j.postharvbio.2006.08.021.

LERSLERWONG, L.; KETSA, S. Autocatalytic ethylene production by Dendrobium flowers during senescence induced by exogenous ethylene. Thai Journal of Agricultural Science, v.41, p.91-99, 2008.

LICHTENTHALER, H.K. Chlorophylls and carotenoids: pigment photosynthetic biomembranes. Methods in Enzymology, v.148, p.362-385, 1987. Available from: <http://www.sciencedirect.com/ science/article/pii/0076687987480361>. Accessed: May 02, 2013. doi: 10.1016/0076-6879(87)48036-1.

MA, G. et al. Effect of 1-methylcyclopropene on the expression of genes for ethylene biosynthesis enzymes and ethylene receptors in post-harvest broccoli. Plant Growth Regulation, v.57, p.223-232, 2009. Available from: <http:// download.springer.com/static/pdf/850/art\%253A10.1007\%252 Fs 10725-008-9339.pdf?auth66 $=13819414962 \mathrm{f} 286 \mathrm{~b} 216 \mathrm{ff} 37 \mathrm{c} 1$ bcb962a1e80e72231\&ext=.pdf>. Accessed: Oct. 13, 2014. doi: 10.1007/s10725-008-9339-7.

MATTIUZ, C.F.M. et al. Longevity of Oncidium varicosum (Orchidaceae) inflorescences treated with 1-methylciclopropene. Ciência Rural, v.42, p.987-992, 2012. Available from: <http:/www.scielo.br/scielo.php?script $=\mathrm{sci}$ arttext\&pid $=$ S0103-84782012000600006\&lng $=$ pt\&nrm $=\mathrm{iso}>$. Accessed: Oct. 28, 2014.

NERGI, M.A.D. et al. Effects of 1-MCP and ethylene on postharvest quality and expression of senescence-associated genes in cut rose cv. Sparkle. Scientia Horticulturae, v.166, p.78-83, 2014. Available from: <http://www.sciencedirect.com/science/ article/pii/S0304423813006432>. Accessed: Sept. 12, 2014. doi: 10.1016/j.scienta.2013.12.015.

PIRRUNG, M.C. et al. Ethylene receptor antagonists: strained alkenes are necessary but not sufficient. Chemistry \& Biology, v.15, p.313-321, 2008.
SA, C.R.L. et al. Métodos de controle do etileno na qualidade e conservação pós-colheita de frutas. Fortaleza: EMBRAPA, Documentos, 2008.36p.

SEGATTO, F.B. et al. Effects of Ethylene on the post-production of potted ornamental peppers (Capsicum annuum L.). Acta Horticulturae, v.1000, p.217-222, 2013. Available from: $<$ http://www. actahort.org/books/1000/1000_28.htm>. Accessed: June 13, 2013.

SEGLIE, L. et al. Use of a non-volatile 1-MCP formulation, N,N-dipropyl (1-cyclopropenylmethyl) amine, for improvement of postharvest quality of ornamental crops. Postharvest Biology and Technology, v.56, p.117-122, 2010. Available from: <http:// www.sciencedirect.com/science/article/pii/S0925521409002567>. Accessed: Sept. 14, 2014. doi: 10.1016/j.postharvbio.2009.12.009.

SEREK, M. et al. Controlling ethylene responses in flowers at receptor level. Biotechnololy Advances, v.24, p.368-381, 2006. Available from: $<$ http://www.sciencedirect.com/science/article/pii/ S0734975006000243>. Accessed: Oct. 2, 2014. doi: 10.1016/j. biotechadv.2006.01.007.

SCHOELLHORN, R. Strategies for plant introduction and market trends in the US. Acta Horticulturae, v.813, p.101-106, 2009. Available from: <http://www.actahort.org/books/813/813_12. htm>. Accessed: Jul. 11, 2013.

SHIMIZU-YUMOTO, H. etal. Effects of ethylene, pollination, and ethylene inhibitor treatments on flower senescence of gentians. Postharvest Biology and Technology, v.63, p.111-115, 2012. Available from: <http://www. sciencedirect.com/science/article/pii/S0925521411002067>. Accessed: Sept. 13, 2014. doi: 10.1016/j.postharvbio.2011.08.009.

TAIZ, L.; ZEIGER, E. Fisiologia vegetal. 3.ed. Porto Alegre: Artmed, 2004. 719p.

WATKINS, C.B.; NOCK, J.F. Production guide for storage of organic fruits and vegetables. NYS IPM, n.10, 2012. Available from: <http://nysipm.cornell.edu/organic_guide/ stored_fruit_veg.pdf $>$. Accessed: Oct. 9, 2014. doi: 10.1016/j. biotechadv. $\overline{2} 006.01 .005$. 